\title{
Corrigendum: Loss of form vision impairs spatial imagery
}

Valeria Occelli ${ }^{1}$, Jonathan B. Lin ${ }^{1}$, Simon Lacey ${ }^{1}$ and K. Sathian ${ }^{1,2,3,4}$

${ }^{1}$ Neurology, Emory University, Atlanta, GA, USA

${ }^{2}$ Rehabilitation Medicine, Emory University, Atlanta, GA, USA

${ }^{3}$ Psychology, Emory University, Atlanta, GA, USA

${ }^{4}$ Rehabilitation R\&D Center of Excellence, Atlanta VAMC, Decatur, GA, USA

${ }^{*}$ Correspondence: valeria.occelli@emory.edu

Edited and reviewed by:

Lotfi B. Merabet, Harvard Medical School, USA

Keywords: blindness, imagery, sense of direction, cognitive style, spatial

\section{A corrigendum on}

Loss of form vision impairs spatial imagery

by Occelli, V., Lin, J. B., Lacey, S., and Sathian, K. (2014). Front. Hum. Neurosci. 8:159. doi: 10.3389/fnhum.2014. 00159

In the Results section, the mean SBSOD scores are erroneously reported as percentages (73 and 69\%). The actual values are 73 and 69.

Conflict of Interest Statement: The authors declare that the research was conducted in the absence of any commercial or financial relationships that could be construed as a potential conflict of interest.

Received: 02 July 2014; accepted: 14 July 2014; published online: 21 August 2014.

Citation: Occelli V, Lin JB, Lacey S and Sathian K (2014) Corrigendum: Loss of form vision impairs spatial imagery. Front. Hum. Neurosci. 8:579. doi: 10.3389/ fnhum.2014.00579

This article was submitted to the journal Frontiers in Human Neuroscience.

Copyright $\odot 2014$ Occelli, Lin, Lacey and Sathian. This is an open-access article distributed under the terms of the Creative Commons Attribution License (CC BY). The use, distribution or reproduction in other forums is permitted, provided the original author(s) or licensor are credited and that the original publication in this journal is cited, in accordance with accepted academic practice. No use, distribution or reproduction is permitted which does not comply with these terms. 